\title{
In vitro and in vivo investigations on anti-influenza effect of adamantyl (alkyl, cycloalkyl) derivatives of aminopropanol-2
}

\author{
O. M. Voloshchuk ${ }^{1}$, Y. V. Korotkiy ${ }^{2}$, S. L. Rybalko ${ }^{3}$, D. B. Starosila ${ }^{3}$, V. P. Shirobokov ${ }^{1}$ \\ ${ }^{1}$ Bogomolets National Medical University \\ 13, Shevchenko Blvd., Kyiv, Ukraine, 01601 \\ 2 Institute of organic chemistry NAS of Ukraine \\ 5, Murmanska Str., Kyiv, Ukraine, 02660 \\ ${ }^{3}$ Gromashevsky L. V. Institute of Epidemiology and Infection Diseases, NAMS of Ukraine \\ 5, Amosova Str., Kyiv, Ukraine, 03038 \\ post-ua@yandex.ua
}

\begin{abstract}
Aim. To establish anti-influenza activities for 8 compounds of adamantyl (alkyl, cycloalkyl) derivatives of aminopropanol-2 in vitro and in vivo investigations. Methods. The antiviral action of compounds was determined in vitro by reduction of infectious titer of the influenza virus in the Madin-Darby Canine Kidney (MDCK) cell culture and in vivo on the model of influenza pneumonia in mice. Results. Three of eight studied compounds inhibit the reproduction of the influenza virus strain $\mathrm{A} / \mathrm{FM} / 1 / 47(\mathrm{H} 1 \mathrm{~N} 1)$ by more than $2 \mathrm{lg} \mathrm{ID}_{50}$ in the concentration range from $<0.39 \mu \mathrm{g} / \mathrm{ml}$ (the compounds 30 and 33) to $1.56 \mu \mathrm{g} / \mathrm{ml}$ (the compound 5), their chemotherapeutic indices are 256 and 16, respectively. The experiments in vivo showed that in prophylactic scheme the efficiency index (EI) of the compounds 5 and 30 is $60 \%$; in therapeutic scheme EI of the compounds 5 and 33 is $100 \%$ that is two times higher, than for rimantadine. Conclusions. High chemotherapeutic indices of the compounds 30,33 and their ability to suppress the influenza virus reproduction in the MDCK cell culture by more than $2 \lg \mathrm{ID}_{50}$ indicate the anti-influenza activity of these compounds. It has been also confirmed by in vivo experiment.
\end{abstract}

Ke y w or d s: influenza virus, adamantyl (alkyl, cycloalkyl) derivatives of aminopropanol-2, antiviral activity.

\section{Introduction}

For today in the world and in Ukraine in particular, is unstable epidemic situation for many infectious diseases, including viral. According to the WHO estimates by 2030, infection dis- eases will be one of the major causes of mortality among people (Antimicrobial resistance: global report on surveillance 2014, http://apps. who.int/iris/bitstream/10665/112642/1/97892 41564748 eng.pdf?ua $=1$ ). Influenza is a leader among the respiratory tract infections by the

(C) 2017 O. M. Voloshchuk et al.; Published by the Institute of Molecular Biology and Genetics, NAS of Ukraine on behalf of Biopolymers and Cell. This is an Open Access article distributed under the terms of the Creative Commons Attribution License (http://creativecommons.org/licenses/by/4.0/), which permits unrestricted reuse, distribution, and reproduction in any medium, provided the original work is properly cited 
number of cases and distribution. Airborne droplets way of distribution of flu infection leads to the rapid spread of the pathogen, and high antigenic variability of the influenza virus results in the appearance of new strains causing epidemics and pandemics. According to the WHO data, the flu and flu-like illnesses affect annually $5-30 \%$ of the world population. The flu and acute respiratory viral infections annually affect about 15 million people in Ukraine [1]. Despite the recent achievements in diagnostics and therapy, the problem of treatment of influenza remains a relevant problem, as well as the establishment of effective chemotherapeutic agents for prevention and therapy of this infection. Nowadays the process of creating new medicines commonly starts from finding new drug candidates - structural prototypes of future chemotherapeutic agents with the desired pharmacological effect [2]. The search for antimicrobial compounds is carried out among new chemical classes as well as among new derivatives of already known compounds affecting certain targets. Since discovery of adamantane its derivatives have proven to be the most promising as viral inhibitors [3-6]. The best of them is aminoadamantane (amantadine, rimantadine) $[3,7]$, which entered the pharmaceutical market and is successfully used as an anti-influenza drug.

The adamantane molecule is highly reactive compared with other hydrocarbons, which allows obtaining a wide range of poly-functional derivatives. The molecule can be modified by the $\mathrm{C}-\mathrm{H}$ bond activation for the direct nucleophilic substitution or radical reactions [8-12]. It can be also modified by the introduction of substituents or heterocyclic atoms for designing new derivatives $[13,14]$.
It is known from literature that amino alcohols and the products of their substitution in the amino and hydroxyl groups have polyvalent pharmacological effects (stimulators or blockers of $\alpha$ and $\beta$-adrenaline, adrenaline mimetics, antibiotics, etc.) $[15,16]$. It is also known that adamantane containing amino alcohols demonstrates antiviral action [17]. The modification of $\beta$-adrena blockers structures via the introduction of various adamantyl fragments as amino groups results in the appearance of antivirus effects [18]. Based on this knowledge it seemed advisable to study an antiviral effect of new adamantane derivatives containing amino alcohols and their related alkyl and cycloalkyl structural analogs $[19,20]$.

\section{Materials and Methods}

\section{The synthesized compounds}

Investigated adamantanyl (alkyl, cycloalkyl) derivatives of aminopropanol-2 were synthesized in Institute of Organic Chemistry of the NAS of Ukraine according to the procedures developed in [15]. The structure and purity of the synthesized compounds were proved via elemental analysis, proton magnetic resonance spectroscopy and chromatography mass spectrometry methods. The common formula of the tested compounds is

$$
\mathrm{ROCH} 2 \mathrm{CH}(\mathrm{OH}) \mathrm{CH} 2 \mathrm{R}^{1}
$$

where: $\mathrm{R}-\mathrm{Ad}\left(\mathrm{CH}_{2}\right)_{2}, \mathrm{R}^{1}$ - cyclohexylamin (the compound 5); $\mathrm{R}-\mathrm{Ad}\left(\mathrm{CH}_{2}\right)_{2}, \mathrm{R}^{1}-1,1,3,3$ tetramethylbutylamine (the compound 6); $\mathrm{R}$ tretbutyl, $\mathrm{R}^{1}-2,2,6,6$-tetraethyl piperidin amine (the compound 33); R - allyl, $\mathrm{R}^{1}$ 1,1,3,3-tetramethylbutyl-amine (the compound 40); R - tret-amyl, $\mathrm{R}^{1}$ - 2,2,6,6-tetramethyl4-hydroxy piperidine amine (the compound 
47); R - cyclopentyl, $\mathrm{R}^{1}$ - 2,2,6,6-tetramethyl4-hydroxy piperidine amine (the compound 48); R - bornyl, $\mathrm{R}^{1}$ - 2,2,6,6-tetramethyl-4-hydroxy piperidine amine (the compound 51). The compounds 48 and 51 were investigated in the alkali form.

Depending on the radicals structure all tested compounds were divided into the adamantane containing (compounds 5 and 6), bornyl containing (the compound 51), the compounds with cyclic substituents in alkoxy group (the compounds 30 and 48) and the compounds with alicyclic substituents in alkoxy group (the compounds 33, 40, 47). All synthesized compounds are colorless and odorless crystalline substances with different solubility in water and $96 \%$ alcohol. The $1 \mathrm{mg} / \mathrm{ml}$ matrix solutions of the studied compounds were prepared using a medium for cell cultures without serum. These solutions were sterilized via filtration through cellulose filter with $0.22 \mu \mathrm{m}$ pore diameter. The solution was stored in sterile bottles at $-20^{\circ} \mathrm{C}$ before using.

\section{Virus and cell culture}

The mouse-adapted influenza virus A/ FM/1/47(H1N1) was cultivated in MadinDarby Canine Kidney (MDCK) cells (ATCC, CCL-34). MDCK cells were cultured in Dulbecco's modified Eagle's medium (DMEM), supplemented with $5 \%$ heat inactivated fetal bovine serum (FBS) in $37{ }^{\circ} \mathrm{C}$ incubator with $5 \% \mathrm{CO}_{2}$. The influenza $\mathrm{A} /$ FM/1/47(H1N1) and MDCK cells were obtained from the Bank of cell cultures of the laboratory of experimental chemotherapy of viral infections of the L. V. Gromashevsky Institute of epidemiology and infectious diseases of NAMS of Ukraine.

\section{Virological tests in vitro}

Anti-influenza activity of the tested compounds was evaluated by chemotherapeutic index (CTI) determined as the ratio of the maximum tolerated dose (MTD) to the minimum active concentration (MAC).

MTD was determined as the greatest concentration of the tested compound that did not cause the cytopathic effect (CPE) in the monolayer of MDCK cells [16, 17]. For this purpose, the growing MDCK cells were plated at a density of $1 \times 10^{5}$ cells $/ \mathrm{ml}$ and incubated in 96-well plates for $24 \mathrm{~h}\left(37^{\circ} \mathrm{C}, 5 \% \mathrm{CO}_{2}\right)$. Then the cells were treated with the tested compounds of different concentration $(3.12,6.25$, $12.5,25,50,100 \mu \mathrm{g} / \mathrm{ml}$ ) for 5 days. The wells containing no compounds were used as a negative control. In the experiments, we used at least ten holes for each dilution of the substance. The CPE was determined by changed cell morphology (degeneration or exfoliation of cells from the hole surface).

MAC of the studied compounds was determined by the degree of reduction of infectious titer of the virus according to the General established procedure $[16,17]$. The virus titers were calculated as $50 \%$ of tissue culture infectious dose $\left(\mathrm{TCID}_{50}\right)$ using the Kerber formula (Manual for the virological investigation of polio, http://apps. who.int/iris/bitstream/10665/ 68762/1/WHO_IVB_04.10.pdf):

Lg TCID $50=$ L-d(S-0.5),

where $\mathrm{L}$ - the initial dilution, $\mathrm{d}$ - the difference between $\mathrm{Lg}$ of serial dilutions, $\mathrm{S}$ - the sum of the proportions of tested objects, which gave a positive result.

The hemagglutination inhibition test (HAI) was carried out to study the influence of tested compounds on the influenza virus hemagglu- 
tination activity (HA). The tested substances diluted in the range of $50-0.36 \mathrm{mkg} / \mathrm{ml}$ were incubated with the virus (4 agglutination units) for $30 \mathrm{~min}$ at room temperature; $0.75 \%$ erythrocytes suspension of Guinea pigs were added, shaken and left at room temperature for $60 \mathrm{~min}$. As a titer of HAI was taken a limiting dilution, which gives a complete delay of the hemagglutination reaction, that is ++++ .

\section{Virological studies in vivo}

The anti-influenza activity of tested compounds was studied via simulation of influenza pneumonia in mice using prophylactic and therapeutic schemes of the compound introduction. In these studies, we used white outbred mice weighing 18-22 g, which were on the standard diet for at least 7 days. All experiments were performed with ten mice per group.

For the prophylactic scheme the mice were intranasally (i.n.) inoculated with $0.2 \mathrm{ml}$ of the tested compounds at $10 \times \mathrm{ID}_{50}(50 \%$-mouse infectious dose; sub-lethal) $24 \mathrm{~h}$ before infection with the influenza virus. For the therapeutic scheme this procedure was carried out $24 \mathrm{~h}$ after infection of mice with the influenza virus. At the same time for both schemes, the control was a group of animals infected with the influenza virus without administration of the tested compounds. The influenza virus strain A/ FM/1/47(H1N1) with infectious titer in the MDCK cell culture $4.5 \lg \mathrm{ID}_{50}$, caused $100 \%$ mortality of control group mice within 5 days. Observation of experimental animals was carried out for 7 days. It was also studied the effect of reference drugs in different regimens of administration to mice with experimental influenza pneumonia. As the reference drugs we used the known flu drugs Tamiflu ${ }^{\circledR}$ of pharmaceutical company F. Hoffman-La Roche, Switzerland (75 mg per capsule) and Rimantadine of pharmaceutical company "Darnitsa", Ukraine (50 mg tablets), which were administered at a dose of $10 \mathrm{mg} / \mathrm{kg}$ of animal weight.

The efficiency of protective action of the compounds was evaluated by the efficiency index (EI) of inhibition of lethality. EI of the tested substances was determined according to the formula [21]:

$$
\mathrm{EI}=\frac{\mathrm{PC}-1}{\mathrm{PC}} \times 100 \%,
$$

where PC - protection coefficient defined as the ratio of the number of animals at the beginning to that at the end of experiment.

\section{Results and Discussion}

The anti-influenza activity of new synthesized adamantyl (alkyl, cycloalkyl) derivatives of aminopropanol-2 was studied against the influenza virus strain A/FM/1/47(H1N1). The antiviral activity of tested compounds $5,6,30$, $33,40,47,48,51$ was evaluated in vitro experiments by their chemotherapeutic index (CTI) determined as the ratio of the maximum tolerated dose (MTD) to the minimum active concentration (MAC). MTD of the tested compounds was determined by their cytotoxic effect on a monolayer of the MDCK cells culture. For this purpose, after 24-h cell growth the nutrient medium was replaced with the medium containing the tested compound in the concentration from $3.12 \mu \mathrm{g} / \mathrm{ml}$ to $100 \mu \mathrm{g} / \mathrm{ml}$. In the control, no replacement was carried out. For the experiments at least ten wells with the cell culture were taken for each dilution of the compound. The level of CPE was determined 


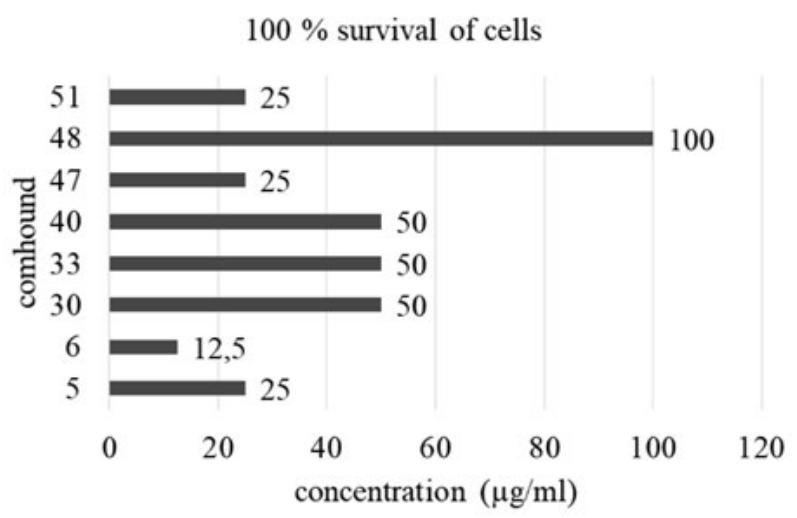

Fig. 1. The MTD of test compounds adamantyl (alkyl, cycloalkyl) of aminopropanol-2 derivatives

by the change in cell morphology (degeneration or exfoliation of cells from the hole surface). MTD of the tested compound was taken as its highest concentration that did not cause degeneration of cells in all ten wells. The results of MTD determination for the studied compounds are presented in figure 1 .

The MAC index of the tested substances was determined in vitro in a monolayer of the MDCK cells cultures by the level of reduction of infectious titer of the virus, in accordance with the General established procedure [16]. With this purpose the test-virus in a dose of $100 \mathrm{ID}_{50}$ in $0.1 \mathrm{ml}$ was introduced into the

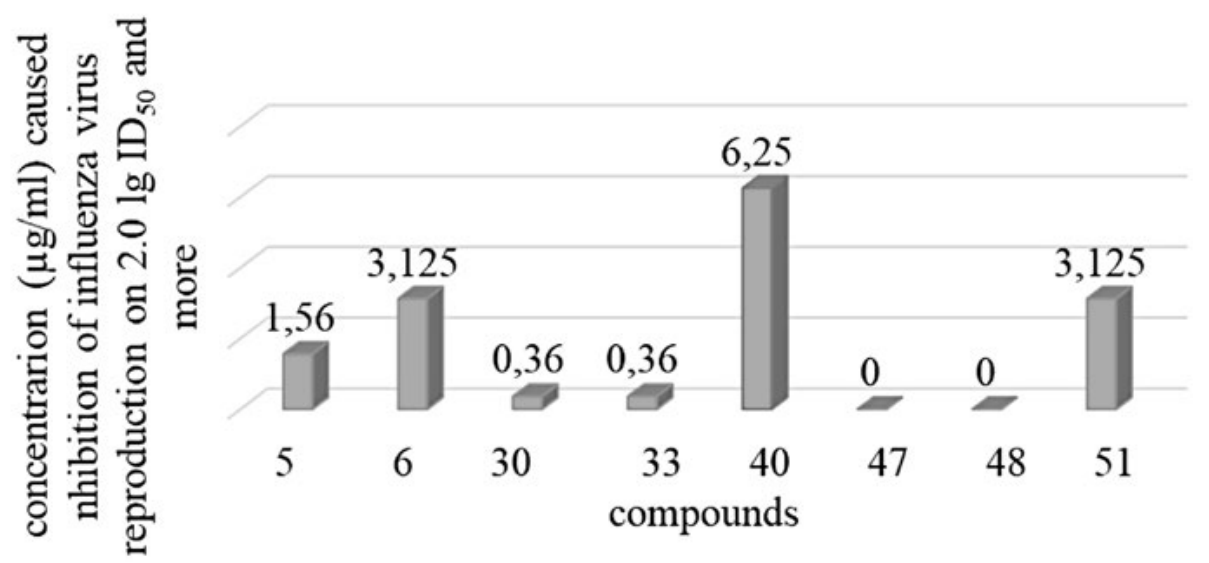

MDCK cells culture and incubated for $1 \mathrm{~h}$ at $37^{\circ} \mathrm{C}$. Next, the virus was removed by washing with medium RPMI-1640, and the support medium (RPMI-1640 + 2\% fetal serum) with the tested compounds in concentration from $0.39 \mathrm{mcg} / \mathrm{ml}$ to $50 \mu \mathrm{g} / \mathrm{ml}$ was added. A reduction of infectious titer in the cell cultures treated with different concentrations of the tested compounds not less than $2 \lg \mathrm{ID}_{50}$ in the experiment compared with control allowed us to establish MAC of the tested compounds for the influenza virus (see figure 2).

According to the data in fig. 2 the compounds 47 and 48 have no influence on the reproduction of influenza virus in the studied concentrations $(0.36 \mu \mathrm{g} / \mathrm{ml}$ to $50 \mu \mathrm{g} / \mathrm{ml})$, they inhibit the development of virus-specific CPE in concentrations less than $2.0 \mathrm{lg} \mathrm{ID}_{50}$. The compounds 5, 6, 30, 33, 40, 51 inhibited the influenza virus reproduction more than 2.0 $\lg \mathrm{ID}_{50}$ in concentrations from of $1.56 \mu \mathrm{g} / \mathrm{ml}$ (compound 5) to $6.25 \mu \mathrm{g} / \mathrm{ml}$ (the compound 40 ), which gives grounds to consider them to possess the antiviral activity. The compounds 30 and 33 were the most active against the influenza virus, their MAC was the smallest and amounted to $<0.39 \mu \mathrm{g} / \mathrm{ml}$.
Fig. 2. The MAC of test compounds for influenza virus. 
O. M. Voloshchuk, Y. V. Korotkiy, S. L. Rybalko et al.

Table 1. The value of CPE and MAC of anti-influenza drugs in relation to the influenza virus

\begin{tabular}{|l|c|c|c|c|}
\hline \multirow{2}{*}{ Concentration of drugs $\mu \mathrm{g} / \mathrm{ml}$} & \multicolumn{3}{|c|}{ anti-influenza drugs } \\
\cline { 2 - 5 } & \multicolumn{3}{|c|}{ Rimantadine } & \multicolumn{2}{c|}{ Tamiflu } \\
\cline { 2 - 5 } & $\mathrm{CPE}$ & $\begin{array}{c}\text { Infectious titer of influenza } \\
\text { virus }\left(\mathrm{Ig}_{50}\right)\end{array}$ & $\mathrm{CPE}$ & $\begin{array}{c}\text { Infectious titer of influenza } \\
\text { virus }\left(\mathrm{Ig}_{50} \mathrm{ID}_{50}\right.\end{array}$ \\
\hline 500.0 & 0 & $\mathrm{NT}$ & 0 & $\mathrm{NT}$ \\
250.0 & 0 & $\mathrm{NT}$ & 100 & $<1.0$ \\
125.0 & 0 & $\mathrm{NT}$ & 100 & $<1.0$ \\
62.0 & 100 & 4.0 & 100 & $<1.0$ \\
31.0 & 100 & 4.0 & 100 & $<1.0$ \\
15.5 & 100 & 4.0 & 100 & $<1.0$ \\
7.75 & 100 & 4.0 & 100 & 4.0 \\
Control of virus & 100 & 4.0 & 100 & 4.0 \\
\hline
\end{tabular}

* NT - not tested

MTD of anti- influenza drugs Rimantadine and Tamiflu was determined by CPE on the monolayer of the MDCK cell culture, and the value of their MAC was established by the degree of reduction of infectious titer of the influenza virus (Table 1). The data in the table 1 show that Rimantadine and Tamiflu were non-toxic to the MDCK cell cultures in a dose

Table 2. MTD, MAC and CTI of the tested compounds, anti-influenza drugs Tamiflu and Rimantadine

\begin{tabular}{|l|c|c|c|}
\hline \multicolumn{1}{|c|}{ compounds } & $\begin{array}{c}\text { MTD, } \\
\mathrm{mcg} / \mathrm{ml}\end{array}$ & $\begin{array}{c}\text { MAC, } \\
\mathrm{mcg} / \mathrm{ml}\end{array}$ & CTI \\
\hline 5 & 25.0 & 1.56 & 16 \\
6 & 12.5 & 3.125 & 4 \\
30 & $>50.0$ & 0.36 & 256 \\
33 & $>50.0$ & 0.36 & 256 \\
40 & $>50.0$ & 6.25 & 8 \\
47 & 12.5 & 0 & - \\
48 & $<100$ & 0 & - \\
51 & 12.5 & 3.125 & 4 \\
Rimantadine & 6200 & 0.36 & 172.2 \\
Tamiflu & 25000 & 0.02 & 12500 \\
\hline
\end{tabular}

of $62.0 \mu \mathrm{g} / \mathrm{ml}$ and $250.0 \mu \mathrm{g} / \mathrm{ml}$ respectively, that corresponds to the value of MTD of these anti-influenza drugs.

The value of ratio of MTD to MAC of the studied compounds, and that of anti-influenza drugs Tamiflu and Rimantadine allowed us to determine their CTI. These data are shown in table 2 .

Table 3. The titer of HAI for compounds 5, 30, 33

\begin{tabular}{|l|c|c|c|}
\hline \multirow{2}{*}{$\begin{array}{c}\text { Concentration } \\
\text { of compounds } \\
\mu \mathrm{g} / \mathrm{ml}\end{array}$} & \multicolumn{3}{|c|}{ The titer of HAI* tested compounds } \\
\cline { 2 - 4 } 50.0 & 5 & 30 & 33 \\
25.0 & - & - & - \\
12.5 & - & $+1+(1 / 512)$ & - \\
6.25 & - & $+1+(1 / 1024)$ & - \\
3.1 & - & $+1+(1 / 1024)$ & - \\
1.55 & - & $+1+(1 / 1024)$ & - \\
0.72 & $+1+(1 / 512)$ & $+1+(1 / 1024)$ & - \\
0.36 & $+1+(1 / 1024)$ & $+1+(1 / 1024)$ & - \\
Control of & $+1+(1 / 1024)$ & $+1+(1 / 1024)$ & $+1+(1 / 512)$ \\
virus & & $+1+(1 / 1024)$ & - \\
\hline
\end{tabular}

HAI * «-»- absence of hemagglutination ; «++++» presence of hemagglutination, titer of HAI 
Table 4. Anti-influenza action of the compounds 5, 30, 33 and the anti-influenza drugs in vivo experiment.

\begin{tabular}{|c|c|c|c|c|c|}
\hline \multirow{2}{*}{ Substances } & \multirow{2}{*}{$\begin{array}{l}\text { Concentration of } \\
\text { substances } \mathrm{mcg} / \mathrm{ml}\end{array}$} & \multicolumn{2}{|c|}{ The number of mice } & \multirow{2}{*}{$\begin{array}{l}\text { Protection } \\
\text { coefficient }\end{array}$} & \multirow{2}{*}{$\begin{array}{l}\text { Efficiency index } \\
\text { (EI), } \%\end{array}$} \\
\hline & & the total number & of them died, (\%) & & \\
\hline \multicolumn{6}{|c|}{ prophylactic scheme } \\
\hline 5 & 1.55 & 10 & $4(40 \%)$ & 2.5 & 60 \\
\hline 30 & 0.36 & 10 & $4(40 \%)$ & 2.5 & 60 \\
\hline 33 & 0.36 & 10 & $8(80 \%)$ & 1.25 & 20 \\
\hline Rimantadine & 0.5 & 10 & $5(50 \%)$ & 2 & 50 \\
\hline Tamiflu & 0.02 & 10 & $2(20 \%)$ & 5 & 80 \\
\hline \multicolumn{6}{|c|}{ therapeutic scheme } \\
\hline 5 & 1.55 & 10 & 0 & $>10$ & 100 \\
\hline 30 & 0.36 & 10 & $4(40 \%)$ & 2.5 & 60 \\
\hline 33 & 0.36 & 10 & 0 & $>10$ & 100 \\
\hline Rimantadine & 0.5 & 10 & $6(60 \%)$ & 1,66 & 39.7 \\
\hline Tamiflu & 0.02 & 10 & $2(20 \%)$ & 5 & 80 \\
\hline Control of virus & 0 & 10 & $10(100 \%)$ & - & - \\
\hline
\end{tabular}

The values of MTD, MAC and CTI of the compounds 30 and 33 correspond to the substances highly active against the influenza virus. CTI of these compounds was equal to 256 and was higher than the same index of the anti-influenza drug Rimantadine, CTI of which was 172.2. The compound 5 is active against the influenza virus, its CTI equal to 16 . The value of CTI of the compounds 6,40 and 51 was also more than 3 (4, 8 and 4 respectively) (Table 2$)$.

It is known that cells are sensitive to the influenza virus, bearing on their surface the receptors to viral glycoprotein of hemagglutinin (HA). The braking hemagglutination activity of the viruses in some cases is associated with a loss of the virus infectivity; therefore, it is appropriate to evaluate the influence of compounds on the hemagglutinin properties of viruses. We examined the influence of the most active compounds 5, 30 and 33 on the hemagglutinate activity of the influenza virus using hemagglutination inhibition test (HAI) (Table 3).

The titer of hemagglutination inhibition was the approved limiting dilution, which gives a complete delay of the hemagglutination reaction. The results of determination of the effect of various concentrations of the tested compounds on hemaglutinin properties of the influenza virus are shown in table 3 . The data in the table 3 show that the compounds 30 and 33 with the same value of MAC $(<0.39 \mu \mathrm{g} /$ $\mathrm{ml}$ ) make different effects on the hemaglutination properties of the influenza virus. The compound 33 influences the virus hemagglutinin in much smaller concentrations than the compound 30 . The HAI titers for the compound № 33 is $0,36 \mu \mathrm{g} / \mathrm{ml}$ and the HAI titer for compound № 30 is only $50 \mu \mathrm{g} / \mathrm{ml}$.

The anti-influenza activity of the tested compounds 5, 30 and 33 was determined in the in vivo experiments on the model of mice 
influenza pneumonia. The efficiency of the protective action of the tested compounds and anti-influenza drugs in the prophylactic and therapeutic schemes of their administration is shown in table 4.

Among the studied substances only the compounds 5 and 30 protect mice from the lethal influenza infection in vivo experiments in the prophylactic scheme of administration (Table 6). Their efficiency indices are equal $(60 \%)$ and higher than the Remantadine EI by $10 \%$. Unlike the substances 5 and 30 the compound 33 did not provide a significant protective effect in the prophylactic scheme of administration. EI of the compound 33 was only $20 \%$, which is much less than that of Tamiflu (80\%). The compounds 5 and 33 showed a much greater protective effect in the therapeutic scheme of administration than in the prophylactic scheme of in vivo experiment. EI of these compounds was $100 \%$ in the therapeutic scheme of administration, compared to the prophylactic scheme, where their EI values were $60 \%$ and $20 \%$ respectively. Comparison of the protective effects of newly synthesized compounds 5, 30, 33 and antiinfluenza drugs Rimantadine and Tamiflu on the model of influenza pneumonia of mice in the prophylactic and therapeutic schemes of their administration is shown in figure 3 .

The EI values of tested compounds 5, 30, and 33 were significantly different for different schemes of the in vivo experiment (Fig. 3). The tested compounds were more effective in therapeutic scheme of their introduction, when influenza drugs showed the same effect in both variants of the experiment. Complete protection against experimental influenza infection in mice was observed for compounds 5 and 33 in therapeutic scheme of their introduction. Their EI values were $100 \%$, that is more than twice higher than Rimantadine EI. The compound 30 showed identical efficiency in different schemes of the in vivo experiment, its

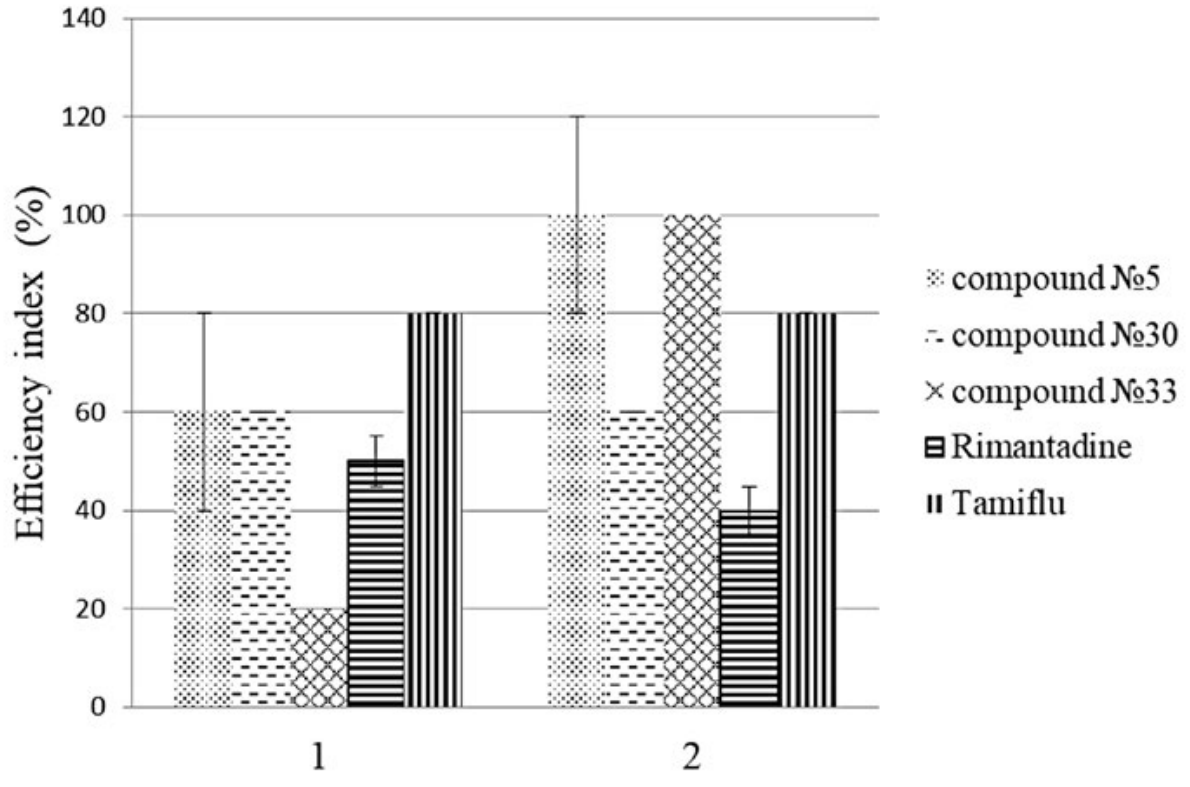

Fig. 3. Anti-influenza activity of the compounds 5, 30, 33 and anti-influenza drugs Rimantadine and Tamiflu on the model of influenza pneumonia of mice in the prophylactic (1) and therapeutic (2) schemes of their administration. 
EI in both cases was $60 \%$. Noteworthy, for the compounds 30 and 33 an equally high CTI (256) was identified in vitro experiment, but these substances showed a different level of protective effect in vivo experiment.

\section{Conclusions}

Among eight tested adamantyl (alkyl, cycloalkyl) derivatives of aminopropanol-2 in vitro and in vivo experiments anti-influenza activity was found for the compounds 5, 30 and 33 . CTI of the compounds 30 and 33 was equally high in vitro experiment on the MDCK cell culture, but these compounds showed different degree of protective effect in vivo experiment on the influenza pneumonia mice model, as well as different influence on hemagglutinin properties of the influenza virus. The compounds 5 and 33 were more effective in the therapeutic scheme of the in vivo experiment, whereas the anti-influenza drugs showed equal effect in both variants of the experiment (the therapeutic and prophylactic schemes of their administration). We suggest that these results may be explained by different mechanisms of action of the tested compounds on the flu virus.

The data obtained give ground to further research of the compounds 5, 30 and 33 for possible elaboration of new antimicrobial drugs on their basis.

\section{REFERENCES}

1. Markovic IG, Grinevich ATh. The analysis of morbidity of influenza of population of Ukraine for 2009-2013. Ukraine. The health of the nation. 2013; 2: 118-24.

2. Pauwels $R$. Aspects of successful drug discovery and development. Antiviral Res. 2006;71(2-3):77-89.

3. Davies WL, Grunert RR, Haff RF, Mcgahen JW, Neumayer EM, Paulshock M, Watts JC, Wood TR,
Hermann EC, Hoffmann CE. Antiviral activity of 1-adamantanamine (amantadine). Science. 1964; 144(3620):862-3.

4. Liu J, Obando D, Liao V, Lifa T, Codd R. The many faces of the adamantyl group in drug design. Eur $J$ Med Chem. 2011;46(6):1949-63.

5. Wanka L, Iqbal K, Schreiner PR. The lipophilic bullet hits the targets: medicinal chemistry of adamantane derivatives. Chem Rev. 2013;113(5):3516-604.

6. Rosenthal KS, Sokol MS, Ingram RL, Subramanian $R$, Fort $R C$. Tromantadine: inhibitor of early and late events in herpes simplex virus replication. $A n-$ timicrob Agents Chemother. 1982;22(6):1031-6.

7. Tsounda A, Maassab H, Cocron K, Evelant W. Antiviral activity of a $\alpha$-methyl-1-adamantane methylamine hydrochloride. Antimic. Agents. Chemother. New Work, 1965; P. 553-560.

8. Akhrem I, Orlinkov A. Polyhalomethanes combined with Lewis acids in alkane chemistry. Chem Rev. 2007;107(5):2037-79.

9. Schreiner PR, Fokin AA. Selective alkane C-H-bond functionalizations utilizing oxidative single-electron transfer and organocatalysis. Chem Rec. 2004; 3(5):247-57.

10. Fokin AA, Schreiner $P R$. Metal-free, selective alkane functionalizations. Adv Synth Catal. 2003; 345(910): 1035-52.

11. Schreiner PR, Lauenstein O, Butova ED, Gunchenko PA, Kolomitsin IV, Wittkopp A, Feder G, Fokin $A A$. Selective radical reactions in multiphase systems: phase-transfer halogenations of alkanes. Chemistry. 2001;7(23):4996-5003.

12. Saunders M, Jiménez-Vázquez HA. Recent studies of carbocations. Chem Rev. 1991; 91(3):375-97.

13. Fleck C, Franzmann E, Claes D, Rickert A, Maison $W$. Synthesis of functionalized adamantane derivatives: $(3+1)$-scaffolds for applications in medicinal and material chemistry. Synthesis. 2013; 45(11): 1452-61. DOI: $10.1055 / \mathrm{s}-0033-1338470$

14. Shvekhgeimer $M G A$. Adamantane derivatives containing heterocyclic substituents in the bridgehead positions. Synthesis and properties. Russ Chem Rev. 1996; 65: 555-98.

15. Korotkii YV, Vrynchanu NA, Dronova ML, Suvorova ZS, Smertenko OA. Synthesis, antibacterial and 
antifugul activity of derivatives of 1[4-(1,1,3,3-tetrametylbutyl) phenoxy-3]-dialkylamino-2-propanol quaternary salts. Farm Zh 2015; 1; 56-62.

16. Shcherbinsky AM, Dyachenko N, Rybalko SL, et al. Study of the antiviral action of potential medical remedies. Method. recommendations. Kyiv, 2001: 528.

17. Volyansky Yul, Gritsenko IS, Shirobokov VP, Dubinina $N$. In: Study of the specific activity of antimicrobial drugs. Method recommend. Kyiv, 2004: 38.

18. Lamoureux G, Artavia G. Use of the adamantane structure in medicinal chemistry. Curr Med Chem. 2010;17(26):2967-78. Review.

19. Shokova EA, Kovalev VV. Adamantane functionalization. Synthesis of polyfunctional derivatives with various substituents in bridgehead positions. Russ $J$ Org Chem. 2012; 48(8):1007-40.

20. Shen $Z$, Lou $K$, Wang $W$. New small-molecule drug design strategies for fighting resistant influenza A. Acta Pharm Sin B. 2015;5(5):419-30.

21. Garashchenko TI, Mezenceva MV. Clinic-immunological basis homeopathic drugs for prophylactics and therapy flu and ORVI. Rus Med J. 2005;13(21): 1432-1437.

\section{Антигрипозна дія адамантил (алкіл, циклоалкіл) похідних амінопропанолу-2 в дослідах in vitro та in vivo \\ О. М. Волощук, Ю. В. Короткий, С. Л. Рибалко, Д. Б. Старосила, В. П. Широбоков}

Мета. Визначити антигрипозну активність у 8 сполук адамантил (алкіл, циклоалкіл) похідних амінопропанолу-2 в дослідах in vitro та in vivo. Методи. Оцінку противірусної дії сполук проводили in vitro за зниженням інфекційного титру вірусу грипу на культурі клітин, та in vivo на моделі грипозної пневмонії у мишей. Результати. В досліді in vitro 3 сполуки серед 8 досліджених пригнічують репродукцію вірусу грипу штаму A/FM/1/47(H1N1) на 2 lg ID $_{50}$ і більше в концентраціях від <0,39 мкг/мл (сполуки №№ 30 і 33) до 1,56 мкг/мл (сполука № 5), їх хіміотерапевтичні індекси стосовно цього вірусу становлять 256 та 16, відповідно. В досліді in vivo при профілактичній схемі досліду сполуки №№ 5 і 30 мають індекс ефективності (IE) 60 \%, а при лікувальній схемі досліду IE сполук
№№ 5 та 33 більше ніж в два рази перевищує цей показник у ремантадину і становить $100 \%$. Висновки. Високі хіміотерапевтичні індекси та здатність пригнічувати репродукцію вірусу грипу на $2 \lg \mathrm{ID}_{50} \mathrm{i}$ більше дозволяє віднести сполуки №№ 30, 33 і 5 до таких, що проявляють протигрипозну активність. Це також підтверджено в досліді in vivo.

К л юч о в і с л о в а: вірус грипу, адамантил (алкіл, циклоалкіл) похідні амінопропанолу-2, антивірусна дія.

Антигриппозное действие адамантил (алкил, циклоалкил) производных аминопропанола-2 в экспериментах in vitro и in vivo

Е. М. Волощук, Ю. В. Короткий, С. Л. Рыбалко, Д. Б. Старосила, В. П. Широбоков

Цель. Определить антигриппозную активность у 8 соединений адамантил (алкил, циклоалкил) производных аминопропанола-2 в экспериментах in vitro и in vivo. Методы. Противовирусное действие исследуемых соединений определяли in vitro по снижению инфекционного титра вируса гриппа в культуре клеток MDCK и in vivo на модели гриппозной пневмонии у мышей. Результаты. 3 соединения среди 8 исследованных подавляют репродукцию вируса гриппа штамм $\mathrm{A} / \mathrm{FM} / 1 / 47(\mathrm{H} 1 \mathrm{~N} 1)$ на $2 \lg \mathrm{ID}_{50}$ и больше в концентрациях от $<0,39$ мкг/мл (соединения №№ 30 и 33) до 1,56 мкг/мл (соединение № 5), их химиотерапевтические индексы (ХТИ) в отношении этого вируса составляют 256 и 16, соответственно. В эксперименте in vivo при профилактической схеме опыта соединения №№ 5 и 30 имеют индекс эффективности (ИЭ) $60 \%$. ИЭ соединений №№ 5 и 33 при лечебной схеме опыта больше чем в два раза превышает этот показатель у Ремантадина и составляет 100 \%. Выводы. Высокие ХТИ и способность подавлять репродукцию вируса гриппа на $2 \operatorname{lg~} \mathrm{ID}_{50}$ и более позволяют отнести соединения №№ 30, 33 и 5 к таким, что проявляют противогриппозную активность. Это также подтверждено в експриментах in vivo.

К л ю ч е в ы е с л о в а: вирус гриппа, адамантил (алкил, циклоалкил) производные аминопропанола-2, антивирусное действие.

Received 05.01.2017 